\title{
Aki megtámadta Pearl Harbort - Iszoroku Jamamoto élete és katonai pályafutása wress
}

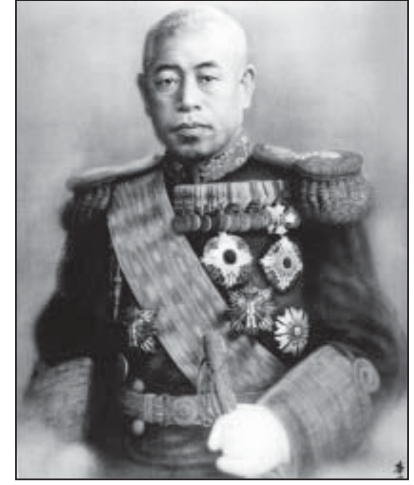

1. ábra. Iszoroku Jamamoto admirális, a japán egyesített flotta föparancsnoka 1939-töl, akit méltán neveztek a modern japán haditengerészet Nelson admirálisának

\section{JAPÁN KAPITALISTA NAGYHATALOMMÁ VÁLÁSA}

A 20. század első évtizedében Japán önellátó lett a nehézipari termékek tekintetében. A külpolitika célkitűzése az ország megerősítése volt, a nyugati hatalmaktól látott módszerek segítségével, azaz területi expanzióval és érdekszférák kialakításával. A terjeszkedő politika felvállalása ugyanakkor nemzeti érdeket is képviselt, hiszen az iparigazdasági fellendülés társadalmi és demográfiai változásokat eredményezett. A gyors népességnövekedés és az ipar nagyarányú fejlesztése miatt a korábban teljesen önellátó Japán az alapvető ipari nyersanyagokból a külföldi beszerzési forrásokra volt utalva. „Japánnak nyersanyagra, szán- tóföldekre és katonai állásokra van szüksége" - hangoztatták az expanziós politikai hívei. A katonai biztonságért folytatott imperialista terjeszkedés így összefonódott a nyersanyag- és piacszerző terjeszkedéssel.

A hadsereg és a hadiflotta modernizálásával - amelyet az ipari-gazdasági fejlődés tett lehetővé - Japán hozzákezdett új külpolitikai törekvéseinek megvalósításához. A kelet-ázsiai térségben azonban komoly vetélytársai voltak: számolnia kellet Oroszország és Kína érdekeivel. A Kurilszigeteket 1875-ben, az oroszokkal kötött szerződés révén szerezte meg Japán. Egy évvel korábban, 1874-ben ellenőrzése alá vonta Tajvan szigetét, 1879-ben pedig a Rjúkjúszigeteket (Okinawa néven), valamint Kínával elismertette

2. ábra. A modern japán hadiflotta egyik első büszkesége, a TOKIWA cirkáló. Méretei: 124 m hosszú és 9700 tonna vízkiszorítású. Fegyverzete: négy, ikerlövegtoronyban elhelyezett $203 \mathrm{~mm}$-es löveg, tizennégy, a hajó oldalán beépített $152 \mathrm{~mm}$-es löveg, páncélvastagsága $180 \mathrm{~mm}$, sebessége 21,5 csomó

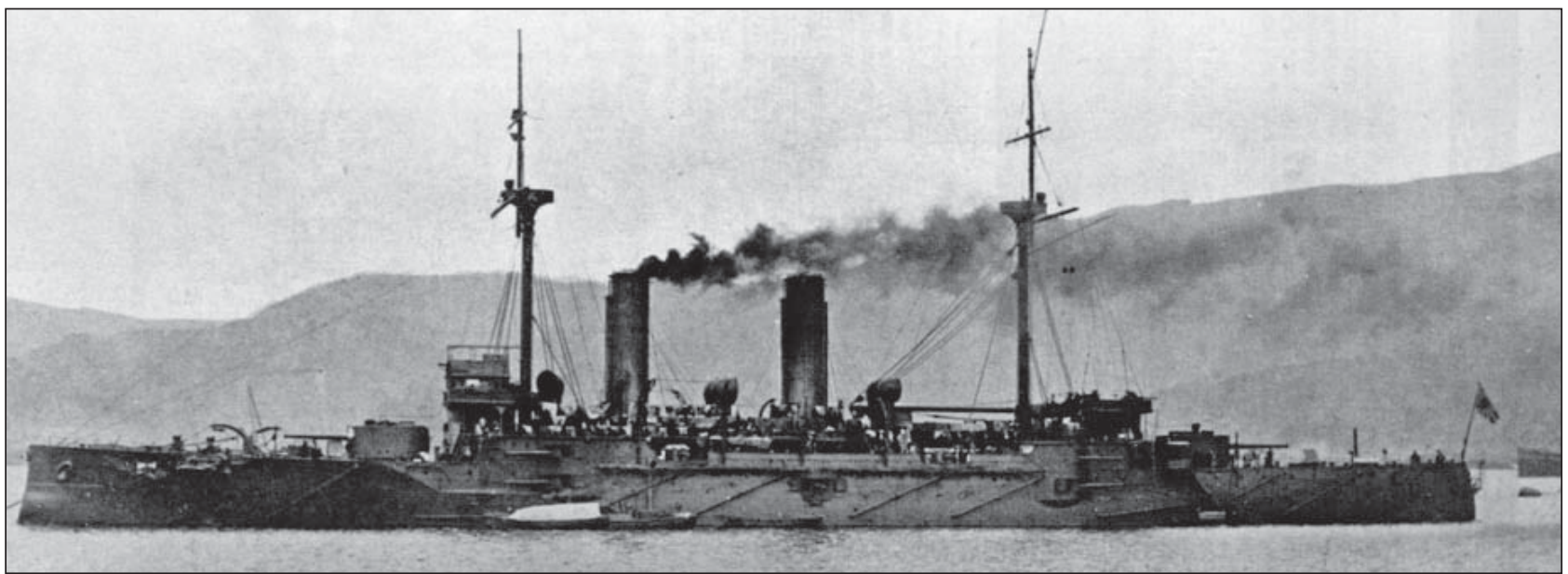

ÖSSZEFOGLALÁS: Iszoroku Jamamoto flottaadmirális a japán haditengerészet egyik legjelentósebb parancsnoka volt. Éveken keresztül tanult és dolgozott az Egyesült Államokban, ami alapvetően meghatározta háborús szemléletét. Neve egybeforrt a Pearl Harbor és Midway elleni hadmúveleti terv kidolgozásával. Az 1940-es évekre nemcsak komoly harci eszközt sikerült kovácsolnia a japán flottából, hanem a légierőre is nagy hangsúlyt helyezett.
ABSTRACT: Marshal admiral Isoroku Yamamoto was one of the most outstanding commanders of the Imperial Japanese Navy. He was studying and working in the United States for many years, and this determined his attitude of mind to war. His name cannot be separated from elaboration of the plans of operations against Pearl Harbor and Midway. By the years of 40s, not only formed he a serious military force from the Japanese fleet, but he attached great importance to the air force, too.

KEY WORDS: World War II, Japanese, navy, aircraft carrier 


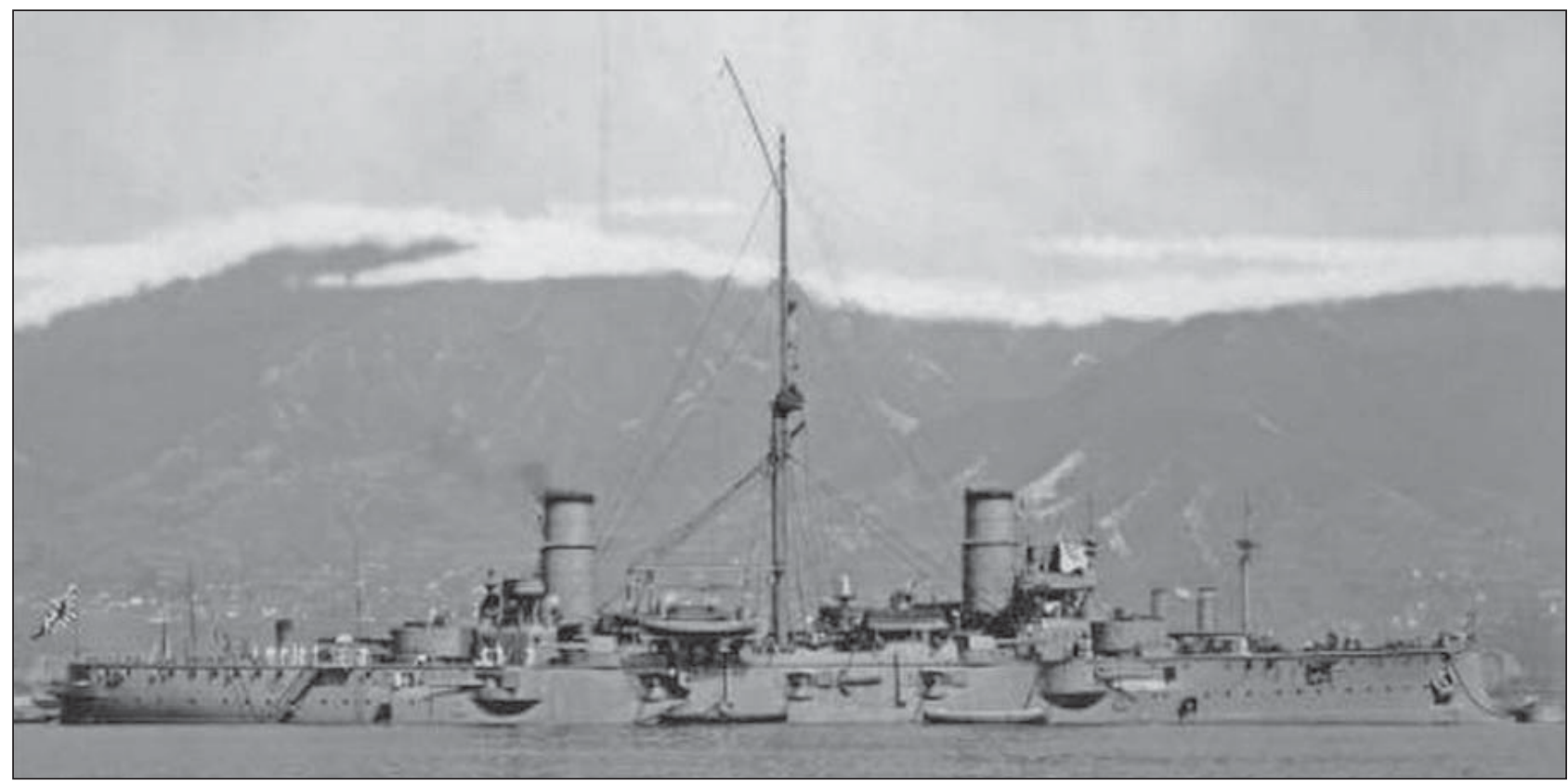

3. ábra. A NISSHIN páncélos cirkáló 1905-ben, az oroszok ellen vívott csuzimai tengeri csata idején 112 m hosszú, több mint 7.500 tonna vízkiszorítás, sebessége 20 csomó

„speciális" érdekeit Koreában (1884). Bár 1885-ben mindkét ország kivonta csapatait a területről, 1894-ben kitört a japán - kínai háború, amelyben Japán 10 hónap alatt győzelmet aratott. Az 1895. április 7-én megkötött shimonoseki béke alapján elismertette Kínával megszerzett birtokait és érdekszféráját (Korea), valamint hadisarc fizetésére kötelezte. Japán koreai terjeszkedése azonban nem csak a kínai, hanem az orosz érdekeket is sértette. Ezért LobanovRosztovszkij orosz külügyminiszter kezdeményezésére Németország, Nagy-Britannia és Oroszország jegyzékben követelte a shimonoseki béke mérséklését. A később „hármas beavatkozás" néven emlegetett tárgyalásokon Japán - mivel nem akarta kitenni fiatal flottáját és hadseregét a megsemmisülés veszélyének - lemondott Liaotungról, valamint elismerte Korea függetlenségét. Az 1894-1895-ös kínai - japán háború a „félgyarmati” státuszból az imperialista nagyhatalmak sorába emelte Japánt, ugyanakkor kiélezte a területi igényekből fakadó orosz-japán szembenállást. Ez az ellentét tovább mélyült 1898-ban: ekkor ugyanis Oroszország bérleti szerződés formájában megszerezte Kínától a vitatott Liaotung-félszigetet, valamint Port Arthur kikötőjét.

\section{A JAPÁN HADITENGERÉSZET GYŐZELME CSUZIMÁNÁL}

Koreában hamarosan az orosz befolyás kezdett meghatározóvá válni, ezért Japán szövetségest keresett magának. 1900-ban a nagyhatalmak oldalán részt vett a boxerlázadás leverésében, aminek révén kivívta Nagy-Britannia tiszteletét és barátságát. Nagy-Britannia egyébként saját érdekei miatt sem zárkózott el a japán szövetség elöl: jól jött az orosz rivális háborúba keveredése Kelet-Ázsiában. 1902ben megszületett a két ország szövetsége, amelyben a britek garantálták: ha egynél több európai országgal keveredik háborúba Japán, hadiflottájuk a segítségére siet. Ezenkívül biztosították szövetségesüket, hogy egy ilyen háborúban nem avatkoznak be az oroszok oldalán. Ez volt az első, egyenrangú paktum egy nyugati és egy nem nyugati ország között. E garancia birtokában Japán készülődni kezdett a vetélytárssal való leszámolásra. Közben Oroszország 1900-ban megszállta Mandzsúria 3 tartományát, illetve Koreában is megerősítette állásait. A két fél közötti háborút lényegében az orosz vezetés robbantotta ki azzal, hogy a japán követelésekre Mandzsúriában katonai összevonással válaszolt, pedig a cári rendszer elmaradottsága és a hatalmas távolság megkérdőjelezte a sikert. Ezzel szemben Japán korszerü hadserege és flottája már a terület közelsége miatt is jó esélyekkel számolhatott, s a háború kimenetelét pontosan ez a tényező döntötte el. A Port Arthur ellen indított, 1904-es tengeri támadás során az orosz távol-keleti flottát sikerült megsemmisíteni a japánoknak, s mire az oroszok mozgósítottak, már elfoglalták a bázist. Ezután Mandzsúriában indítottak támadást: 1905 februárjában, a Mukdennél vívott ütközetben az orosz szárazföldi haderő döntő vereséget szenvedett. Oroszország erre a Balti-tengerről Afrika megkerülésével a Csendes-óceánra küldte európai flottáját, amelyet azonban a Japán és Korea közötti Csuzimai-szorosban Togo Heihachiro admirális meglepetésszerűen megtámadott és teljesen megsemmisített.

Theodore Roosevelt, amerikai elnöknek 1905. szeptember 5-én a New Hampshire-i Portsmouth-ban sikerült tárgyalóasztal mellé ültetni a szembenálló feleket. $A z$ itt kötött egyezmény alapján Japán visszakapta Liaotungot, megszerezte a Szahalin-sziget déli részét, illetve a mandzsúriai vasútvonalak bérleti jogát, valamint Koreát és Mandzsúriát mentesítették az orosz be-

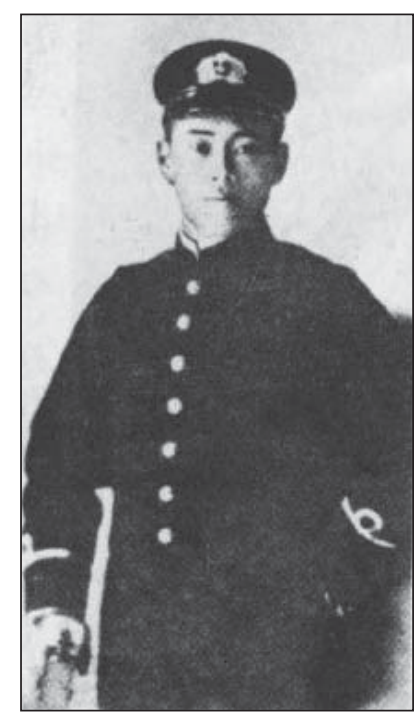

4. ábra. Jamamoto 1905-ben zászlósként szolgált Togo admirális mellett 


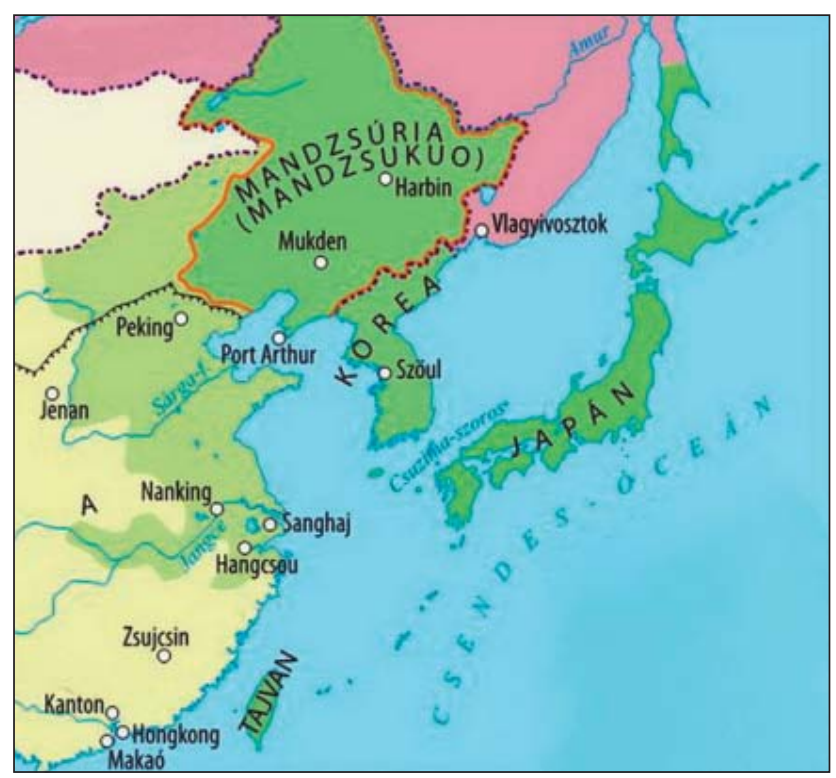

5. ábra. Japán terjeszkedése a 20. század első évtizedeiben

folyás alól. Háborús jóvátételt azonban nem kapott. Ito Hirobumi, Korea japán kormányzójának meggyilkolása miatt, 1910-ben Japán annektálta a területet.

A Kína és Oroszország ellen folytatott, sikeres területszerző háborúk bizonyították a japán tengeri és szárazföldi haderő, illetve az expanziós külpolitika életképességét. A fegyveres erők tekintélye megnőtt. A Csuzimánál aratott fényes győzelem Togo admirális taktikáját dicséri: meglepetésszerü, hadüzenet nélküli támadás. Ennek fontosságát az admirális mellett zászlósként szolgáló Iszoroku Jamamoto is felismerte, aki 36 évvel később - a második világháború egyik legnagyobb tehetségű stratégájaként újra bebizonyította a hadüzenet nélküli támadás eredményességét.

\section{Jamamoto tanulóével Japánban És aZ Egyesült Államokban}

Iszoroku Jamamoto (eredeti nevén Iszoroku Takano) 1884. április 4-én született Nagaokában. Édesapja iskolamesterként dolgozott, Iszoroku a hetedik gyermek volt a családban. Gyermekkorára hatással voltak a Meidzsi-korszak nyugati tendenciái: rendszeresen sportolt, a nagaokai középiskolában harcművészeteket tanult. Imádott baseballozni, pedig ez nem mondható tipikus japán sportnak. Szorgalmasan tanulmányozta a keresztény Bibliát. Egy amerikai misszionárius segítségével tanulta meg az angol nyelvet, édesapjától pedig a kínai írásjeleket.

15 évesen elhatározta, hogy a haditengerészetnél fog karriert építeni. 1901-ben jelentkezett a birodalmi haditengerészet akadémiájára: 300 jelölt közül a harmadik legjobb eredménynyel teljesítette a felvételi vizsgát Etajimában, az akadémia székhelyén. Főként a fegyverkezéssel foglalkozott, kimeríthetetlen tudásvággyal tanulmányozta a haditengerészet ezen szakterületét. Ennek meg is lett az eredménye: az akadémián eltöltött három év alatt a téma szakértőjévé vált, 1904-ben kitűnő eredménnyel szerezte meg diplomáját.

1905-ben belépett a birodalmi haditengerészet kötelékébe: fedélzeti parancsnok és fegyverkezési szakértő lett a NISSHIN cirkáló fedélzetén, amelyet 1905. május 27-én a csuzimai tengeri csatában is bevetettek. Jamamoto - aki Togo admirális zászlósaként részt vett az ütközetben - később így emlékezett vissza az eposzba illő csatára: „Nem

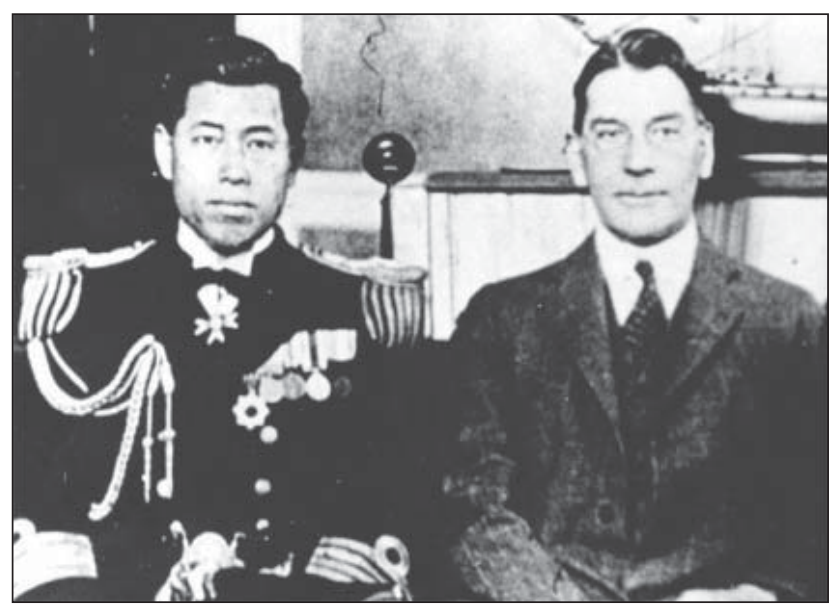

6. ábra. Jamamoto mint tengerészeti attasé Curtis Wilsonnal, az USA tengerészeti minisztériumának munkatársával, 1925-ben

éreztem félelmet, pedig a lövedékek csak úgy röpködtek a fejem fölött. A NISSHIN-t találat érte, én pedig elvesztettem az eszméletem. Mikor magamhoz tértem, a jobb lábamon hatalmas seb tátongott, a bal kezemröl pedig két ujjam hiányzott. De a győzelmünkhöz nem fért kétség: még a sebesültek is éljeneztek." Bár Jamamoto két ujját hagyta ott a csatában, mégis fontos dolgot tanult meg: a győzelem kulcsa a meglepetésszerű, hadüzenet nélküli támadás. Két hónapig lábadozott, de ezt az időt is hasznosan töltötte: tanulmányozni kezdte a világpolitikát, főként Anglia haditengerészeti erejével foglalkozott.

A csuzimai csatában való részvétel kiváló ajánlólevél volt, karrierje gyorsan emelkedett: 1905 augusztusában a haditengerészet yokosukai bázisára került, ahol szeptemberben alhadnaggyá nevezték ki. 1907-ig szolgált itt. Ezután a KAGERO nevű cirkálóra került, 1908-tól pedig Mandzsúria térségében, a MAEZURU fedélzetén teljesített szolgálatot. Közben tengerész föhadnagyi rangot kapott, s a Torpedóiskola tanfolyamát is elvégezte.

1913-tól három évig a haditengerészet vezérkari főiskoláján tanult Tsukijiben. Közben 1915-ben parancsokká léptették elő. 1916-ban szerzett diplomát a vezérkari főiskolán: végzettsége magas pozíció betöltését ígérte. Szolgálatot teljesített a II. tengeri hadiflotta vezérkaránál, majd a hadügyi iroda II. osztályához került.

7. ábra. Jamamoto (a kép közepén) a londoni tengerészeti konferencián 1935-ben, a japán küldöttség tagjaként

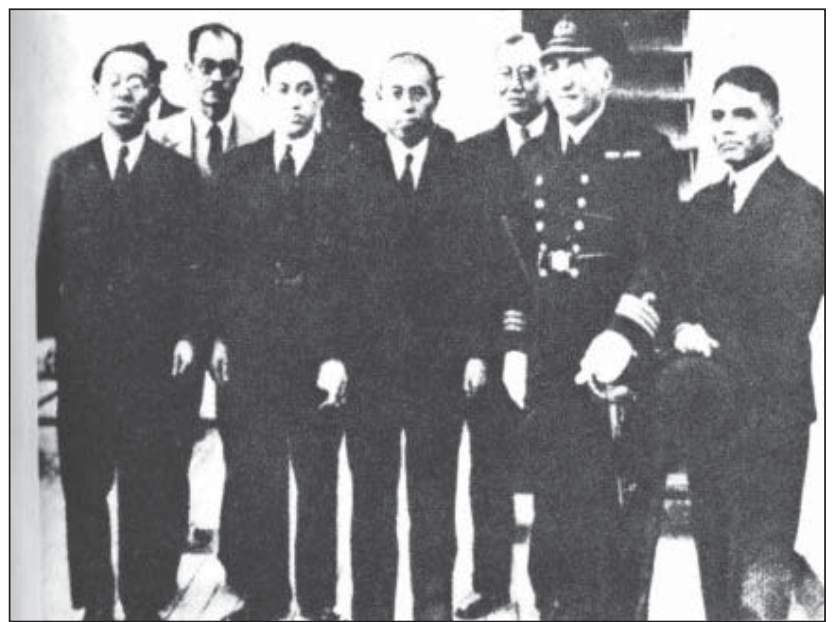



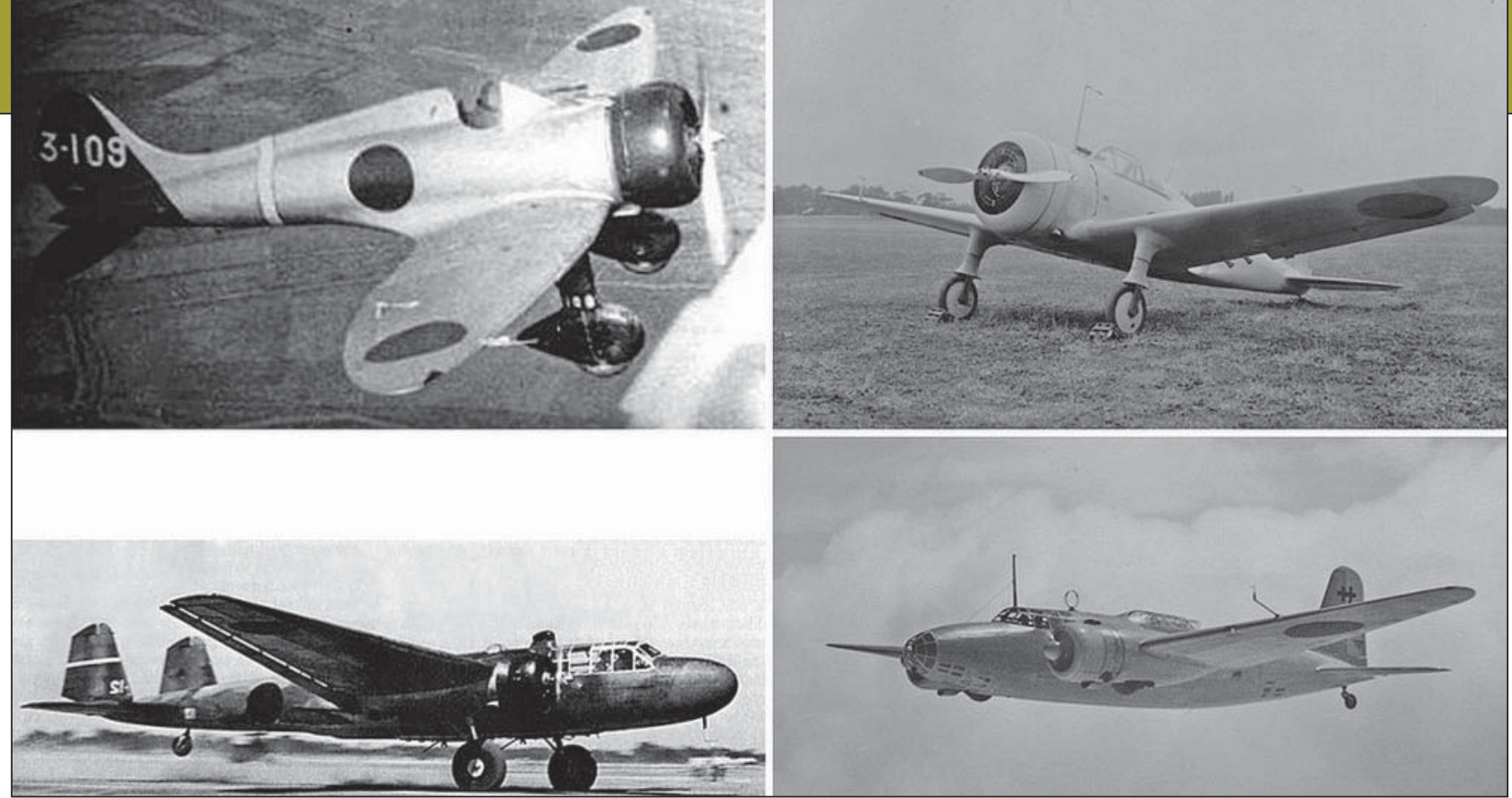

8. ábra. A japán légierő legkorszerübb repülőgépei a '30-as évek végén: a Mitsubishi A5M (balra fenn), a Nakajima KI-27-es (jobbra fenn), illetve a Mitsubishi G3M és KI-21-es (alul)

Ezalatt tovább folytatódott Japán nagyhatalmi terjeszkedése is: azzal, hogy 1914 augusztusában hadat üzent Németországnak, bekapcsolódott az első világháborúba. Japánt nem érdekelte az európai háború, csupán két dolgot akart megvalósítani: a távol-keleti vetélytárs Oroszország gyengítését, illetve a területszerzést. Könnyűszerrel megszerezhette ugyanis Németország kínai gyarmatát, Kiaocsou kikötőjét. A kínai kormány nem számíthatott nagyhatalmi támogatásra, ezért 1915-ben aláírta a 21 japán követelést elismerő szerződést. Közben elfoglalták a Mariana-, a Karolina-, és a Marshall-szigeteket, majd 1918-ban az intervenciós haderő Kelet-Szibéria partvidékén is megjelent: Japán eséllyel pályázhatott a kelet-ázsiai hegemóniára.

Mialatt az első világháború utóvihara tombolt, Jamamoto 1919 áprilisában az Egyesült Államokba hajózott: a Massachusetts állambeli Cambridge-ben beiratkozott a Harvard Egyetem külföldiek számára indított kurzusára, ahol közgazdaságtant tanult, illetve az amerikai olajipart tanulmányozta, hiszen ekkor japán fő importcikke az olaj volt. Hihetetlen szorgalma itt is megmutatkozott: éjszakákon keresztül foglalkozott az olajipar történetével és ágazataival. Az élet azonban nemcsak munkából állt. A harvardi évek alatt került kapcsolatba élete két nagy szenvedélyével: a pókerrel és a harcászati repüléssel. Ebben szerepe volt William Mitchell amerikai tábornoknak, aki egy merőben új harcászati elmélettel állt elő: hordozókról indított repülőgépek képesek lehetnek elpusztítani egy hadihajót. Álítását sokan kétségbe vonták, Jamamoto azonban látott benne fantáziát. 1923-ban szerzett diplomát a Harvardon, itt is kitűnő eredménnyel végzett. Szaktudását, szorgalmát sokan elismerték, hiszen több amerikai olajtársaság munkát ajánlott neki. Ő azonban hűséges maradt hazájához és annak hadiflottájához.

A harvardi évek alatt értékes tapasztalatokat szerzett az Egyesült Államok mérhetetlen gazdasági erőforrásairól. Ezen tapasztalatok később ráébresztették arra, hogy egy esetleges japán-amerikai háborúban a hatalmas emberi és gazdasági erőforrások lényegesen jobb esélyt biztosítanának az Egyesült Államok számára.

Mielőtt elhagyta az USA-t, körbeutazta az országot: gyárakat, üzemeket látogatott meg Detroitban, eljutott a délamerikai olajmezőkre is, így közvetlenül megismerhette „Uncle Sam” hatalmas ipari erejét. Autóstoppal Mexikóba is eljutott: az olajipar technikai-hálózati felépítéséről akart ismereteket szerezni. Itt azonban kényes helyzetbe került: kémkedés vádjával letartoztatták, s csak a japán nagykövetség közbenjárására engedték szabadon. 1923-ban, 39 éves korában tért vissza Japánba.

\section{A MILITARIZMUS ELÖRETÖRÉSE JAPÁNBAN}

A '30-as években a liberalizálódó tendenciák háttérbe szorultak, az expanzió, a militarizmus, az ultranacionalizmus lett a meghatározó irányelv a japán politikában. Az ultranacionalizmus első jelei már a Meidzsi-korszakban megmutatkoztak: az idegenellenes tiltakozó megmozdulások las-

9. ábra. A ZUIKAKU repülőgép-hordozó 1941. szeptember 25-én, szolgálatba állásának napján. Fegyverzete $16 \mathrm{db} 127 \mathrm{~mm}$-es ágyúból és $36 \mathrm{db} 25 \mathrm{~mm}$-es légvédelmi gépágyúból állt, átlagosan 84 repülőgépet szállított)

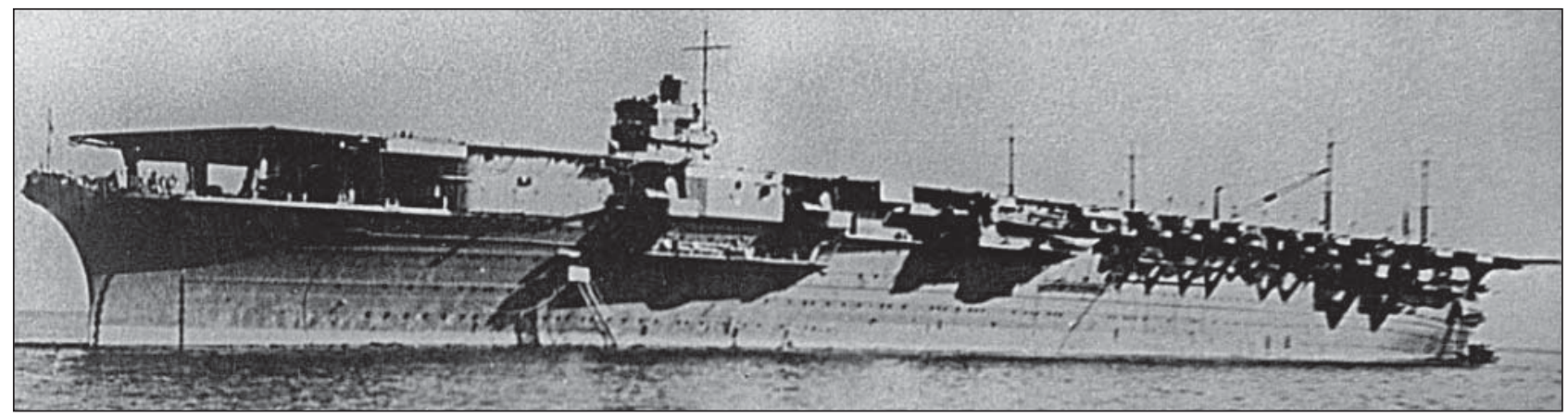




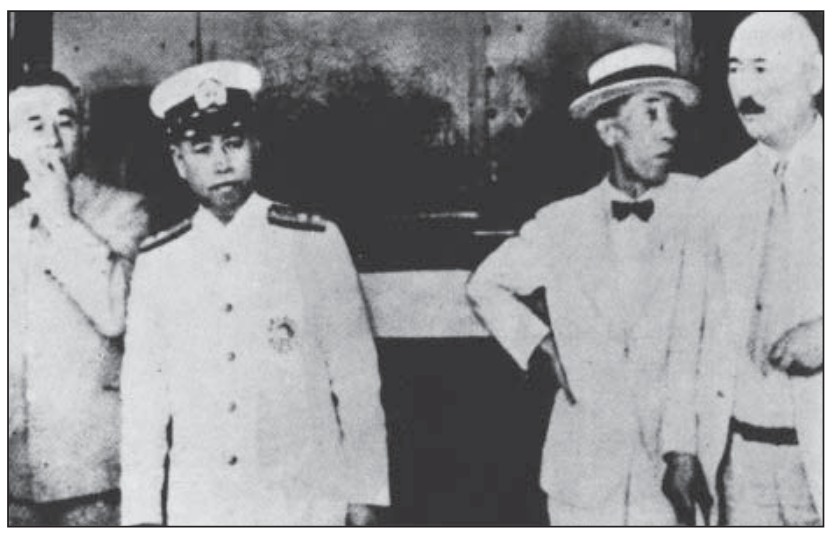

10. ábra. Jamamoto admirális átveszi az egyesített flotta parancsnokságát 1939. augusztus 31-én

san önálló mozgalommá váltak, amelynek célja a pánázsiai eszme megvalósítása, illetve a nyugati terjeszkedéssel szembeni fellépés volt. 1881-ben alakult meg a Genjosa nevű szervezet, majd 1901-ben a Kokurjukai: elsődleges céljuk volt a hadsereg és a haditengerészet vezető szerephez juttatása, valamint a nyugati demokratikus vívmányok eltörlése. Ragaszkodtak a tradíciókhoz, így élvezték az alsóbb népcsoportok támogatását is.

Az első világháború utáni rendezésben kezdett körvonalazódni a japán-amerikai ellentét. Ez abból fakadt, hogy a kelet-ázsiai japán expanzió sértette az Egyesült Államok érdekeit, ezért hamar sor került az első diplomáciai összetűzésre. Ez Santung kérdése miatt robbant ki. A területre Japán és Kína egyaránt igényt tartott, így a döntés a nagyhatalmakra várt.

Az 1921 novemberétől 1922 februárjáig tartó washingtoni konferencián Japán kénytelen volt beleegyezni Santung és a kelet-szibériai partvidék kiürítésébe, valamint tengeri fegyverkezésének korlátozásába (flottája 60\%-a lehet az USA és Nagy-Britannia tengeri haderejének).

Az ipari-demográfiai növekedés ellenére az ország egyre inkább a külföldi nyersanyag- és élelmiszerforrásoktól függött. Az ipar és a népesség eltartására ki kellett építeni a japán gyarmatbirodalmat, amely a terjeszkedés révén biztosítja a létfontosságú nyersanyagokat (olaj, kaucsuk, ásványkincsek).

A hadsereg 1932-ben leválasztotta Kínáról Mandzsúriát, s „Mandzsukuo” néven japán bábállammá tette, majd 1933/1934 során Belső-Mongóliában és az észak-kínai területeken is megerősítette állásait. A Nyugat ellenlépéseit teljesen figyelmen kívül hagyták, ami egyértelművé tette, hogy Japán külpolitikáját nem a kormányzat, hanem az expanzió mellett elkötelezett hadsereg irányítja. A terjeszkedés irányában azonban nem volt egyetértés: a brit mintára szerveződött hadiflotta délre, az indonéz kőolaj és az angol-amerikai támaszpontok felé fordult volna, a hadsereg viszont északon tervezett kontinentális expanziót.

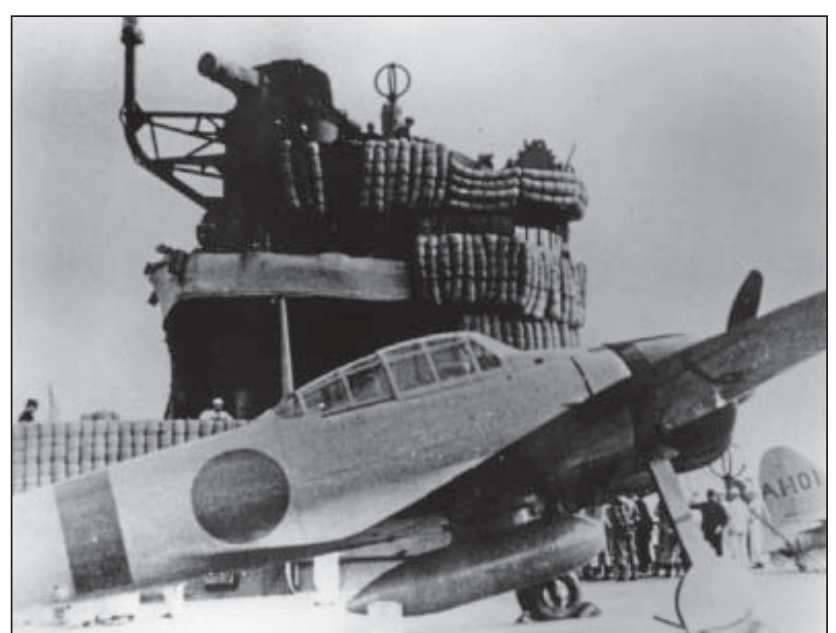

12. ábra. Egy Zero vadászrepülőgép az AKAGI hordozó fedélzetén, 1941. december 7-én

1937 után a hadsereg befolyását tovább növelte a Kormányzati Tervhivatal létrejötte, amivel a katonaság saját ellenőrzése alá vonta a pénzügyek irányítását. A kínai háború irányítására jött létre a Birodalmi Főhadiszállás (Dai hon 'ei): ez hozta a legfontosabb döntéseket, a polgári kormányzatnak pedig csak egy dolga maradt, támogatni a hadsereget. Amikor Japán és az USA között elkerülhetetlenné vált a háború, a kettős kormányzatot egyesítették: 1941. október 18-án Tojo Hideki tábornok lett egy személyben a miniszterelnök, a hadügyminiszter és egy ideig a belügyminiszter is. Ezzel teljessé vált Japánban a hadsereg uralma.

\section{JAMAMOTO PÁLYAFUTÁSA 1941-IG}

Még 1920-ban jelent meg William Mitchell, amerikai tábornok azon nyilatkozata, mely szerint elképzelhető egy valamikori, meglepetésszerü japán támadás Pearl Harbor ellen. Jamamoto akkor ezt képtelenségnek tartotta: „Nem osztom Mitchell tábornok véleményét a két ország viszonyával kapcsolatban. Sosem tekintettem Amerikát ellenségnek, s Japán tervei sem tartalmazták soha a két ország közötti háború lehetőségét."

Ez a személyes vélemény azonban nem volt helytálló: a '30-as évekre egyértelmű volt Japán expanziós szándéka, ami előrevetítette a két ország egymásnak feszülését. S ez meghatározta Jamamoto pályafutását is. Miután hazatért a Harvardról, a KITAKAMI cirkálón, később pedig a FUJI cirkálón teljesített tiszti szolgálatot, majd 1924-től a légierő Kasimigaurában lévő kiképzőbázisának vezetője lett, rendkívüli fegyelmet gyakorolva: kötelezővé tette az egyenruhát, a kopaszra borotvált fejet, s a tantervet is szigorúan alakította át. 1925-ben visszatért az USA-ba, tengerészeti

11. ábra. A SHOKAKU repülögép-hordozó 1941 augusztusában, szolgálatba állásakor

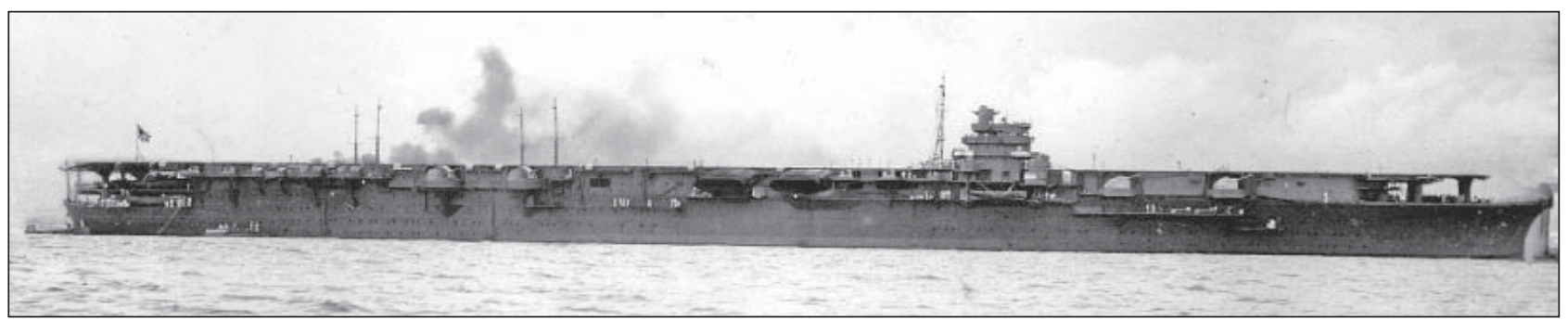




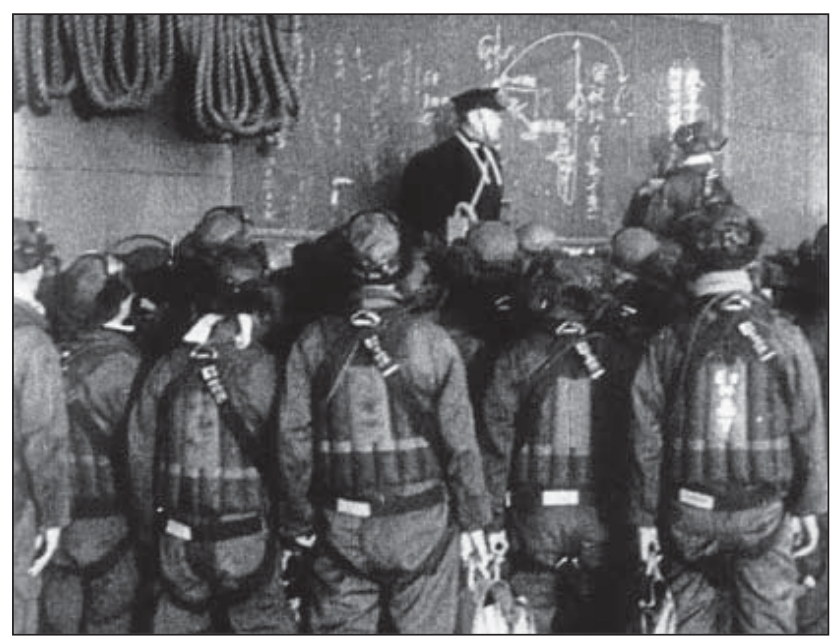

13. ábra. A japán pilóták utolsó eligazítása a támadás előtt, az egyik hordozó fedélzetén

attasé lett a washingtoni japán nagykövetségen, így közvetlenül tanulmányozhatta az USA véderejét és haditengerészeti tevékenységét, valamint kapcsolatot alakíthatott ki a hadsereg és a hadiflotta vezető tisztjeivel. Ellis Zacharias, flottakapitány személyesen is ismerte Jamamotót, akit visszaemlékezésében így jellemzett: „Az attasét nagyon érdekelte a háború... A repülőgép-hordozó, a tengeri és légi haderő kombinációja a rögeszméjévé vált... Mindig úgy éreztem, hogy Pearl Harbor megtámadásának gondolata itt, Washingtonban merült fel benne először."

$A z$ attasé két évig teljesített diplomáciai szolgálatot az USA-ban, Amerika iránti csodálata széles körben ismertté tette. Magánleveleiből azonban kiderül, hogy ez a csodálat inkább csak a gazdasági-ipari nagyhatalomnak szól: az USA flottáját kártyajátékosok és golfjátékosok társaságának, békeidős haditengerészetnek nevezte.

Japánba visszatérve az AKAGI hordozó parancsnoka lett, 1929-ben a haditengerészet hivatalában dolgozott. 1930-ban a légiflotta parancsnoka, majd ellentengernagygyá léptetik elő, a haditechnikai részleg vezetésével bízzák meg. 1935-ben tagja volt a londoni tengerészeti konferencián résztvevő japán delegációnak, ahol hazája hadiflottáját további korlátozásokkal sújtották. Ezután tengerészeti és légi fegyverek kifejlesztése lett a feladata, ami már a háborút vetítette előre. A légierő erőteljes fejlesztésébe kezdett: 1937-ben 1511, 1940-ben pedig már 4768 gépből állt a japán légiflotta. A vadászgépek közül a Mitsubishi A5M és a Nakajima KI-27-es, a bombázók közül a Mitsubishi KI-21-es és G3M volt a leghatékonyabb ezekben az években.

A hadiflotta megerősítését is kulcskérdésnek tartotta, ezért tervet dolgozott ki az 5:3 arányú fejlesztésre az USAval és Nagy-Britanniával szemben: elrendelte két, modern repülőgép-hordozó, a 34 csomós végsebességü, 30000 tonnás SHOKAKU és ZUIKAKU megépítését.

1939-ben admirálissá és az egyesített flotta parancsnokává nevezték ki. Ez a pozíció lehetővé tette számára a pilóták kiképzésének reformját, kötelezővé téve az éjszakai gyakorlatokat. Úgy vélte, egy esetleges háborút csak meglepetésszerű támadásokkal lehet megnyerni, ezért a japán pilótáknak éjjel-nappal képesnek kell lenniük a repülésre.

Miközben hazája harcászati fejlesztésén fáradozott - ellentétben többi tiszttársával - Jamamoto mindenáron el akarta kerülni a háborút az Egyesült Államokkal. Konoye miniszterelnök 1940-ben paktumot írt alá Hitler Harmadik Birodalmával és Mussolini fasiszta Olaszországával. Az admirális ezt mélységesen ellenezte: tisztában volt vele, hogy Japánnak kevés esélye van a végső győzelemre, ha belekeveredik egy elhúzódó háborúba. De a történelem fonalát ő sem volt képes befolyásolni: hazája nagy léptekkel haladt a háború felé. Miután Japán a második világháború elején szövetségre lépett Németországgal és Olaszországgal, Jamamoto világosan látta, hogy az USA-val történő konfrontáció immár elkerülhetetlen. Kételyeinek többször hangot adott, érvei azonban süket fülekre találtak a japán vezetésben.

\section{Pearl Harbor, 1941. december 7.}

A '30-as évektől érezhetően megromlott a viszony Japán és a nyugati világ között, mivel a távol-keleti ország egyenértékű haditengerészetet szeretett volna Nagy-Britanniával és az USA-val, ezt azonban korábban mindhárom tengerészeti konferencián (1921: Washington, 1930: London, 1935: London) megtagadták tőlük. Ezért indította el nagyarányú flottafejlesztési programját, amelyben Jamamoto is fontos szerepet játszott.

Egyre erőteljesebben kiéleződött Japán és az USA ellentéte, főként Kína kapcsán, ezt azonban ténylegesen a Panay-incidens mélyítette el 1937-ben. Egy nappal Nanking eleste előtt, december 11-én a japán haditengerészet repülői támadást indítottak a Jangce folyón horgonyzó kínai hajók ellen. A támadás során azonban négy angol ágyúnaszádot, három amerikai tankhajót és a PANAY nevű, amerikai ágyúnaszádot is elpusztították. Az USA hadat üzenhetett volna, de az ügyet elsimították. Ebben nagy szerepe volt Jamamotónak, aki mint megbízott tengerészeti miniszter biztosította az USA nagykövetét, hogy a haditengerészet nem tesz többé ilyen lépéseket. Ennél fontosabb azonban, hogy sem az amerikai kormány, sem az amerikai közvélemény nem készült fel a hadba lépésre.

1938-ra a japán Birodalmi Hadsereg kínai lépései a hódítás jellegét öltötték fel. A katonai vezetés elsődleges célja volt elvágni Kínát a nyugati hadianyag- és élelmiszer-utánpótlástól. Az USA válasza erre az volt, hogy 1939 nyarán az USA felbontotta kereskedelmi egyezményét Japánnal (ez előrevetítette a későbbi olaj- és acélembargót).

1940. szeptember 27-én Japán, Németország és Olaszország aláírta a háromhatalmi egyezményt, amely szerint az USA hadba lépése esetén kölcsönösen segítik egymást. Figyelmeztetés volt ez az USA-nak. Japán elsődleges célját akarta megvalósítani: felszabadítani Ázsiát „a fehér ember igája” alól. A háborús lépéseket a politikát befolyásoló hadsereg is támogatta, s bármennyire ellenezte Jamamoto a Nyugattal szembeni fellépést, meg kellett hajolnia a nemzet elvárásai előtt. Már 36 éve szolgált a haditengerészetnél, s eddig sem volt stílusa a visszavonulás, vagy a császár parancsainak megszegése. Most is eleget tett kötelezettségeinek: hozzálátott a terv kidolgozásához. Elképzelésének az adott alapot, hogy az USA kettéosztotta flottáját atlanti- és csendes-óceáni egységekre, s a csendes-óceáni flottát áthelyezték San Diegóból a Hawaii szigetekhez. A japánok ezzel a haderővel akartak összecsapni, mégpedig a következőképp: az amerikai flottát japán vizekre kell csalni, majd a tengeralattjárók és a cirkálók révén a tenger fenekére küldeni, valahol a keletkínai tengeren. Ezután villámháborús ütemben lerohanják Délkelet-Ázsiát, elfoglalják Szingapúrt, Thaiföldet, Burmát, Malajziát, a Fülöp-szigeteket és a holland kelet-indiai szigetvilágot, majd védelmi vonalat húznak a megszerzett területek köré, hogy kiaknázhassák azok erőforrásait. Ez volt a „kantajkesszen”, a „mindent eldöntő támadás” terve. 


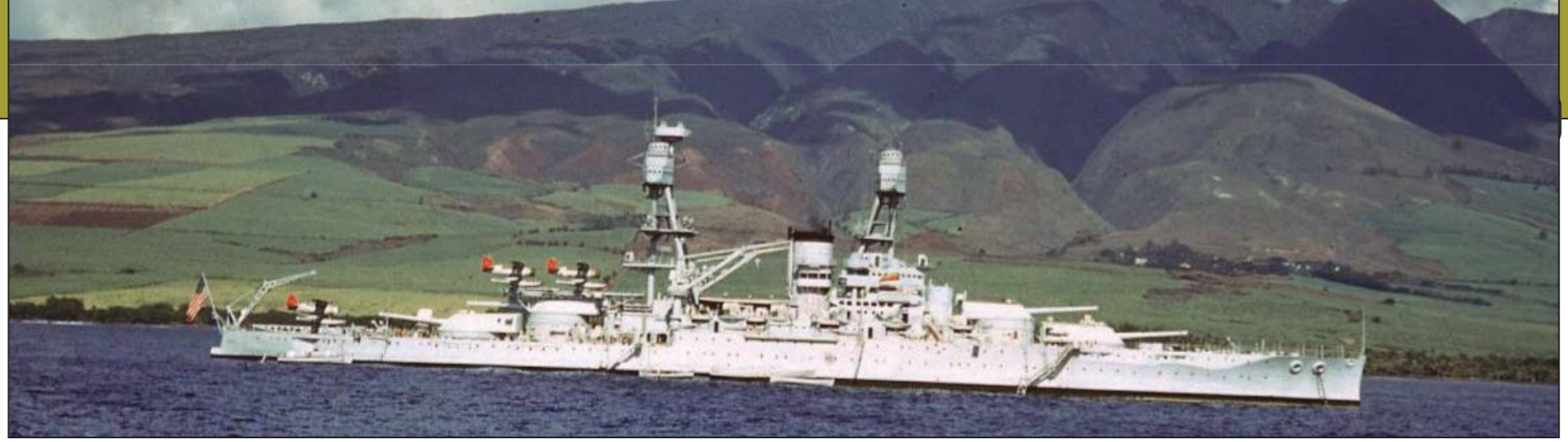

14. ábra. A PENNSYLVANIA csatahajó a háború előtti állapotában a Pearl Harbouri kikötő öblében

Jamamoto minden tudását, amit az amerikai hadseregről szerzett, beleszőtte a tervbe. A csuzimai csata óta tudta, mekkora előny van a meglepetésszerű támadásban, ezért itt is erre alapozta számításait: csak az amerikai flotta hadüzenet nélküli megtámadása és megsemmisítése után sikerülhet Délkelet-Azsia lerohanása. Amikor előhozakodott tervével, ötletét szinte a teljes japán haditengerészeti vezérkar ellenezte. Nem a stratégiával, hanem a módszerrel volt bajuk: ő ugyanis az egész támadást a repülőgép-hordozókra, s nem a csatahajókra alapozta. A japán flotta 1941 decemberében 6 nehéz hordozóval (KAGA, AKAGI, HIRYU, SORYU, SHOKAKU, ZUIKAKU) és 4 könnyű hordozóval (HOSHO, RYUZIO, TAIYO, ZUIHO) rendelkezett. Ezekből hatot akart használni a támadás során. Mindenki tudta, hogy egy hordozó igen értékes eleme a háborúnak, s mindenki félt attól, hogy mi történne, ha a támadás alatt védtelen hordozókat megtámadnák az ellenséges cirkálók. Jamamoto ezen a téren is nyugodt volt: a védelmi szerepet a japán csatahajóknak és tengeralattjáróknak szánta, bár a nagy távolságból indított támadás miatt erre nem is valószínű, hogy szükség van. A haditengerészetet azonban ezzel sem nyugtatta meg. Ohnisi ellentengernagy soknak tartotta a bekalkulált veszteséget. Az admirális viszont meggyőzően próbált érvelni: „Ha nem mérünk megelőző csapást, és nem tesszük harcképtelenné az amerikaiakat, nem egyforma eséllyel indulunk velük. Érthetö, hogy nagy veszteségekre számít, de az elért eredmény megérné az áldozatot." Tarsolyában az egyik alaptrükk a japán parti támaszpontú haditengerészeti légierő kiépítése volt: ha a hordozók odavesznek, a szigeteken kialakított felszállópályák még támogathatják a japán hadsereg malájföldi és fülöp-szigeteki hadmúveleteit. Érvelését végül is siker koronázta: Ohnisi és a vezérkar fiatalabb tagjai támogatták a javaslatot.

A terv ellenére Jamamoto ragaszkodott álláspontjához: 1940 őszén megtette utolsó, híressé vált nyilatkozatát, amelyben figyelmeztette Konoye miniszterelnököt a háború negatív következményeire: „Ha ragaszkodik hozzá, hát belevágok a háborúba, és megígérhetem, hogy másfél évig pokollá teszem az életüket. De azzal kapcsolatban semmit sem garantálhatok, mi fog történni azután..." Ugyanakkor egy magánlevélben így fogalmazott: „Ha hosszan tartó háborúba keveredünk az USA-val, nem lesz elég elfoglalnunk Guamot és a Fülöp-szigeteket, de még Hawaii-t és San Francisco-t sem. Be kell vennünk Washingtont és a Fehér Házban aláiratnunk a békeszerződést." Ez nyilvánvalóan meghaladta Japán képességeit.

Közben Minoru Genda parancsnok kidolgozta a Pearl Harbor elleni támadás részletes tervét: meglepetésszerű támadást kell mérni az hordozókkal a fő célpontra és a szárazföldi támaszpontú repülőgépekre az Oahu-szigeten. A támadás két hullámban, legalább hat hordozóról történne zuhanóbombázók, valamint torpedóbombázók segítségével.

A kivitelezéshez azonban több dolgot is tenni kellett: április 10-én átszervezték az Egyesített Flottát, megalakult az öt hordozóból álló Első Légi Flotta, Chuichi Nagumo altengernagy vezetésével (Nagumo rangidősként került ebbe a pozícióba, s ő is roppant kockázatosnak tartotta
Jamamoto tervét). Genda parancsnok pedig intenzív torpedókiképző-programot indított el a Kyusu-szigeten, ahol a terep hasonlított Pearl Harborra. Gondot jelentett azonban az amerikai hajók torpedókkal történő megsemmisítése. Torpedókat ugyanis csak ott lehetett repülőgépekről bevetni, ahol a vízmélység meghaladta a 25 métert. A Pearl Harbor-i kikötő vízmélysége azonban átlag 10 méter volt. Genda vezetésével erre is találtak megoldást: a $800 \mathrm{~kg}$-os torpedók testére fa stabilizátorokat szereltek, ezekkel az „úszók"-kal már sekély vízben is sikeres támadást lehetett végrehajtani.

\section{(Folytatjuk)}

\section{FELHASZNÁLT SZAKIRODALOM}

1. Edwin O. Reischauer: Japán története Maecenas Kiadó, Budapest, 1995;

2. Rondo Cameron: A világgazdaság rövid története a kőkorszaktól napjainkig, Maecenas könyvek, Budapest, 1998;

3. Colcutt - Jansen - Kumakura: A japán világ atlasza, Helikon Kiadó, Budapest, 1997;

4. Farkas Ildikó: Az ellentmondások földje: Japán História 2001/2.;

5. Diószegi István: A hatalmi politika másfél évszázada, História-MTA Történettudományi Intézete, Budapest, 1997;

6. Biography of Yamamoto www.goldenessays.com/ alphabetic/1/biographies/yamamoto.htm;

7. Tora! Tora! Tora! Hadi Krónika 21. szám;

8. Isoroku Yamamoto: Japan's Unwilling Warrior Pearl Harbor's World War II Collector's Edition - The Official 50th Anniversary Magazine, New York, 1991;

9. Holmes-Benett: A háborúk világtörténete, Corvina Kiadó, Budapest, 1999;

10. Edwin P. Hoyt: Pearl Harbor, Agora Kiadó, Budapest, 1999;

11. Ivor Matanle: A második világháború, Merhávia Kiadó, Budapest, 1997;

12. Endresz István: Kuriózumok az 1939-1945-ös

légiháborúból VIII-X. www.altonova.hu/forszazs/legiero;

13. Dr. Végh Ferenc: Pearl Harbour orosz szemmel. Haditechnika 2010/1;

14. Kenneth Macksey: A II. világháború katonai tévedései, Alexandra Kiadó, Pécs, 1996;

15. N. N. Jakovlev: Pearl Harbor rejtélye, Kossuth Könyvkiadó, Budapest, 1978;

16. Rázsó Gyula: Végzetes japán győzelem História, 1992/2.;

17. Ábel András: Los Alamostól Nagaszakiig Püski Kiadó, Budapest, 1995;

18. Edwin P. Hoyt: Vér és verőfény Holnap Kiadó, Budapest, 1992;

19. Winston Churchill: A második világháború II. Európa Kiadó, Budapest, 1999;

20. Museum honors man who planned Pearl Attack www starbulletin.com/1999/04/14/news/story14.html. 